\title{
FLOUTING MAXIMS IN “BEAUTY AND THE BEAST” MOVIE
}

\author{
Safrida Florentina ${ }^{1}$ \\ Universitas Putera Batam, Batam, Kepri, Indonesia \\ Pb181210040@upbatam.ac.id \\ Ambalegin, Ambalegin ${ }^{2}$ \\ Universitas Putera Batam (UPB), Batam, Kepri, Indonesia \\ Ambalegin@puterabatam.ac.id
}

\begin{abstract}
Communication is one of important part in human life. This research related to the phenomenon of pragmatics. This research focused on analyzing the flouting of maxims in the Disney film entitled "Beauty and the Beast". The purpose of this study is to determine the kinds of maxim flouting produced by the actor. For this research, the researchers used Grice's theory of flouting maxim. This research used descriptive qualitative as the research design which shapes how the report of the analysis would be descriptively. This research collected the data by applying observational and non-participatory technique by Sudaryanto (1993). As for analyzing data, the researchers used pragmatic identity method and pragmatic competence- in equalizing technique. From the analysis of the collected data, the researchers found that several conversations of the main characters in this film contained flouting of the maxims. Those were 4 data of maxim quantity, 4 data of maxim quality, 3 data of maxim of relevance, and 2 data of maxims manner.

Keywords: Flouting maxim, maxim of manner, maxim of quantity, maxim of quality, maxim of relevance
\end{abstract}

\section{INTRODUCTION}

In human life cannot be separated from communication, namely using language. Mcafee (2004) conveyed that many linguists apply Whorf's hypothesis about language, which states that how people use language influences how they perceive the world. How language is used in communication is important in the case of pragmatics as a branch of linguistics. Pragmatics is the study of what a speaker means when interacting. In a nutshell, pragmatics is the study of meaning that is influenced by factors other than language. To understand what is going on in a conversation, for example, we must first understand how relationships and social distance work between them, as well as their relative status.

Communication must be done using simple, easy to understand and 
efficient language to establish relationships between speakers in the community. However, language is also described as a literary work, like a film or movie. What is known is that the film is a picture of the public about their actions and conversations. Then the two elements serve to connect one event to another that creates a conversation between the speaker and the listener. Based on Ambalegin \& Suryani (2018), speakers must understand the meaning of what they uttered and formed it in a simple way so that the listener understands what has been said.

The phenomena that researchers found in movie of Beauty and The Beast shown in below the conversation:

\begin{tabular}{|c|c|}
\hline Bookseller & : “Ah, Belle!" \\
\hline Belle & $\begin{array}{l}\text { :"Good morning. I've } \\
\text { come to return the } \\
\text { book I borrowed." }\end{array}$ \\
\hline ookseller & : "Finished already?" \\
\hline elle & $\begin{array}{l}\text { : "Oh, I couldn't put } \\
\text { it down! Have you } \\
\text { got anything } \\
\text { new?" }\end{array}$ \\
\hline ooksell & $\begin{array}{l}\text { :"Not } \\
\text { yesterday." }\end{array}$ \\
\hline
\end{tabular}

The conversation above in movie Disney beauty and the beast in minute was no error in the structure, but there was an error in the response made by bookstore and belle. Which is a question asked by a bookstore should provide a response that is in accordance with the question. Logically if someone asks a question like bookstores do, then the appropriate answer is "yes, I'm ready to read it". And in fact, what Belle responded was beyond what was asked.

According to Grice (as cited in Kurniati \& Hanidar, 2018), when a speaker flouts a maxim they may fail to fulfill it. Unlike violating a maxim where a speaker tends to mislead and cause the hearer to misunderstand, maxim flouting takes places when the speaker decides not to obey the cooperative principle so that hearer will infer the hidden meaning behind the utterance that is literally spoken by the speaker. In the context of the conversation can be seen the relationship of the conversation if one of the speakers or listeners is not comfortable with unclear responses. There is no longer any connection between the previous question and the answer. In simple terms, there are several types of flouting maxim that cause uncooperative principles that affect the effectiveness of the conversation.

There are two previous research of flouting maxims. The first was done by Marlisa \& Hidayat (2020). The researchers investigated the flouting maxims in Good Morning America (GMA) talk show which had Jackie Chan as the guest star. The research used the theory of Grice and took GMA talk show as the data source. The results found out that the highest flouting maxims were flouting the maxim of quantity and manner. Further, the study also revealed the rationales behind maxims flouting which were good to create fun communication and to elaborate more explanations.

The next research was conducted by Op.sunggu \& Afriana (2020). It examined the flouting maxims in "Wonder Women" movie. The data source was the movie and the theory of Grice was implemented. The findings found out that four of types were done in the movie. The dominant type was maxim of relations which were mostly 
done by the main character of the movie.

Based on the explanation above, the principle of cooperation is made to create a well-connected conversation. By following the principle of cooperation, that is hoped that the community will understand and prevent misunderstandings. However, in "Beauty and The Beast" actors speak uncooperatively. As a result, creates an unclear and sometimes ambiguous meaning for other actors who play in the film. Then, the previous and present research showed the similarity as the present research used the same theory. The difference is this present research took "Beauty and the Best" movie. Thus, this study found the types of flouting maxim that caused the uncooperative principle such as, maxim quality, maxim quantity, maxim relevant, and maxim manner.

\section{LITERATURE REVIEW}

In communicating, somebody tends to be more communicative so that the messages to be transmitted are understood by the speaker or listener. According to Mey (2018), communication requires people to cooperate the bare facts of conversation come alive only in a mutually accepted pragmatically determined context. Based on study linguistics, this will be closely related to the cooperative principal proposed by $\mathrm{H}$. Paul Grice where the principle of cooperation applies four maxims, namely maxim quality, maxim quantity, maxim relevant and maxim manner. The cooperative principle can contribute to your dialogue as needed. To show that don't give more or less information to listeners (Op.Sunggu \& Afriana, 2020).

According to the above definition of the cooperative principle, both the speaker and the listener must have a mutual desire to convey and interpret the meaning of an utterance. Furthermore, the speaker and listener must collaborate to ensure that communication runs smoothly. As previously stated, Grice's proposed cooperation principle is comprised of four maxims (Meyer, 2009), which are as follows:

\section{a. Maxim of Quantity}

Grice divided the quantity maxim into two parts. The first is Make your contribution as informative as is necessary for the current purposes of the exchange. The second rule is to not make your contribution any more informative than necessary. Here is the example of quantity maxim in the below(Salzmann et al., 1999):

Diana : People's agendas changed overnight. I was now the separated wife of the Prince of Wales, I was a problem, I was a liability (seen as), and how are we going to deal with her? This hasn't happened before.

Bashir: Who was asking those questions?

Diana: People around me, people in this environment, and . .

Bashir: The royal household?

Diana: People in my environment, yes, yes.

\section{b. Maxim of Quality}

According to Grice's (Yule, 1996) quality try to make your contribution one that is true. The first, do not say what you believe to be false. The 
second, do not say that for which you lack adequate evidence. Here's the example of quality maxim in below(Yule, 2015):

A friend's father considers whether to buy your friend a new car, and you are aware that the old car has broken down before.

A : should I buy my son this new sport car?

B improper : I do not know if that is such a good idea, his car runs fine.

B proper : yeah, that sounds like a good idea, his car has broken down before.

c. Maxim of Relevance

A : ugh, I wonder what time it is..... B improper : it is 6.30

B proper : it is 6.30. So, you have the whole night ahead of you! Have you eaten at Hardy's before?

\section{d. Maxim of Manner}

According to Yule (2015), avoid obscurity of expression; Avoid ambiguity; Be orderly. Here's the example below:

A : can you take out the trash?

B improper : well, it is probable that I would take out the trash more often if someone were not flagrantly wasteful, such that, the majority of trash was not always coming from that person.

B proper : Sure, but we need to talk about how we are assigning the chores around here when I get back.

Then (Grice, n.d.) reiterated the statement on the principle of cooperation, that anyone who cares about the goals that are central to conversation/communication (such as giving and receiving information, influencing, and being influenced by others) must be expected to have an interest, given suitable circumstances, in participation in talk exchanges that will be profitable only on the assumption that they are conducted in general accordance with the cooperative principle and the maxims.

Based on what Grice has said, it is possible to conclude that the principle of cooperation must be applied in communication in order for it to run smoothly, clearly, and without confusion. However, in practice, the speaker is unable to follow all of the principles in the principle of cooperation, resulting in a violation of the maxim. However, it cannot be said that violating maxims is always a bad thing because a speaker will have a specific reason for violating maxims, such as making his statement more polite.

Thomas (1995) stated that when a speaker violates a maxim or a cooperative principle, he does not expect anything negative to happen, but he does expect the interlocutor to win the hidden meaning in his utterance because he cannot pronounce it directly. Thomas also stated that such communication techniques may be more effective in conveying messages in this manner.

When there is a flouting of maxims in an utterance, it will cause an implicature or hidden meaning of the utterance. As mentioned by Levinson (2000), conversational implicatures are meanings that are understood by speech participants but are not and are not revealed in what is said. And describes the four uses of the concept of implicature, namely: 
1. The concept of implicature allows meaningful functional explanation of linguistic facts that are not reached by linguistic theory

2. The concept of implicature provides a clear/explicit explanation of how it is possible that what is said outwardly is different from what is meant, and that the language user understands (captures) the intended message.

3. The concept of implicature can simplify the semantic description of the different relationships between clauses, even though the clauses are connected with the same structural words.

4. Some of the basic points of implicature can explain various facts/symptoms outwardly seem unrelated and/or contradictory (such as metaphors).

As a result, it is possible to conclude that a violation of maxims in an utterance will result in a hidden meaning or implicature of the utterance. The context surrounding the speech should then be examined in order to analyse the implicature.

\section{RESEARCH METHOD}

In order to shape the expected quality of the result, the research establishes proper methodology in identifying the flouting maxim. The research design employs a qualitative approach proposed by (Creswell, 2007) This method provides descriptive data that is both textual and contextual. The data was gathered using the observational method of Sudaryanto (1993). It was done by watching the phenomenon in the data source Disney's Beauty and the Beast film. The technique makes use of non- participation as a data source because the research could not present and experience the phenomenon directly. The process begins with (1) watching the episode, (2) holding the script and marking the theoretically relevant utterances while watching, and (3) describing the context of the selected utterances on the second viewing. Because context is important in analyzing utterances, the data is analyzed using the pragmatic identity method by Sudaryanto (1993). The data was analysed by employing the pragmatic competence- in equalizing data.

\section{FINDINGS AND DISCUSSION}

4.1 Findings

\begin{tabular}{|c|c|}
\hline $\begin{array}{c}\text { Types Flouting } \\
\text { Maxim }\end{array}$ & Some utterances of Flouting Maxims \\
\hline \multirow{4}{*}{$\begin{array}{l}\text { Flouting } \\
\text { Maxim of } \\
\text { Quantity }\end{array}$} & $\begin{array}{l}\text { "It is about two lovers in Fair } \\
\text { Verona." }\end{array}$ \\
\hline & $\begin{array}{l}\text { "It's the ones who play hard to get } \\
\text { that are always the sweetest prey." }\end{array}$ \\
\hline & "I've come for my father." \\
\hline & "The master of his castle." \\
\hline \multirow{4}{*}{$\begin{array}{l}\text { Flouting } \\
\text { Maxim of } \\
\text { Quality }\end{array}$} & "I was lost in the woodsand." \\
\hline & $\begin{array}{l}\text { "Except the west wing... which we do } \\
\text { not have." }\end{array}$ \\
\hline & $\begin{array}{l}\text { "Please, I mean no harm. I just } \\
\text { needed a place to stay." }\end{array}$ \\
\hline & $\begin{array}{l}\text { "Maurice, thanks heaven! I've spent } \\
\text { the last five days trying to find you." }\end{array}$ \\
\hline \multirow[t]{3}{*}{$\begin{array}{l}\text { Flouting } \\
\text { Maxim of } \\
\text { Relevance }\end{array}$} & $\begin{array}{l}\text { "Well, not that one. But you know } \\
\text { books.. for you dinner table (giving } \\
\text { bunch of flower) shall I join you this } \\
\text { evening?" }\end{array}$ \\
\hline & "I had an expensive education" \\
\hline & "You're welcome" \\
\hline \multirow{2}{*}{$\begin{array}{l}\text { Flouting } \\
\text { Maxim of } \\
\text { Manner }\end{array}$} & $\begin{array}{l}\text { "She's so well read... and you are so } \\
\text { athletically inclined" }\end{array}$ \\
\hline & $\begin{array}{l}\text { "You are the wildest.. most gorgeous } \\
\text { thing I have ever seen. Nobody } \\
\text { deserves you. But at least I know our } \\
\text { children will be beautiful." }\end{array}$ \\
\hline
\end{tabular}

The utterances were found based on the conversation on the "beauty and the beast" movie of the all participant 
in the movie. The researchers then categorized utterances based on the types of flouting maxim. Those are flouting maxim quality, flouting maxim quantity, flouting maxim manner, flouting maxim relation.

\subsection{Discussion}

In fact, the four maxims are not always followed by the speakers in communication. When the maximum communication is not followed or not followed, then "Floating Maxims" is referred to. (Thomas, 1995) said in his book "When a maxim is blurred, the speaker will not mislead the listener but wants the listener to see the conversational implications, the meaning of this utterance is not expressed in the words spoken." From Thomas said above's conclusions, the researcher can be concluded that the expert hopes of the opponent who was present when the speaker failed to maximize communication.

There are several flouting maxims criteria based on Grice maxims that serve as distinguishing guidelines Levinson 1983 and Coulthard 1987(Barat, 2017) They are flouting the maxim of quantity, the maxim of relation, and the maxim of manner.

\subsubsection{Flouting maxim quantity}

There are several reasons why the participants flouting the quantity maxim. He or she employs circumlocution. It denotes that the participant does not get to the point. In this case, the participant provides either too little or too much information. Finally, the participant usually violates this maxim because he or she uses insufficient words when speaking. It means that when he or she speaks, he or she uses incomplete words.

Datum 1

$$
\begin{aligned}
& \begin{array}{c}
\text { Monsieur Jean : "Where are you } \\
\text { off to?" }
\end{array} \\
& \text { Belle }
\end{aligned}
$$

Monsieur Jean : "Sounds boring."

During the conversation, Belle flouting the quantity maxim by saying, "It's about two lovers in Fair Verona." According to Grice's maxim of quantity theory, make your contribution as informative as is required, but in the conversation, Belle give more information about the book that should not be delivered, because the additional information that Belle give may be irrelevant or unnecessary.

Datum 2

$\begin{array}{ll}\text { Lefou } & \text { : "So moving on?" } \\ \text { Gaston } & \text { : “No, Lefou! It's } \\ \text { the ones who play } & \text { hard to get that } \\ & \text { are always the } \\ & \text { sweetest prey. } \\ & \text { That was makes } \\ & \text { Belle so appealing, } \\ & \text { she hasn't made a } \\ & \text { fool of herself just } \\ & \text { to gain my favor. } \\ & \text { What would you } \\ \text { call that?" }\end{array}$

According to Grice's theory about the maxim of quantity, which states that both the speaker and the hearer must contribute, he explained why he does not want to move on from Belle with the sentence "It's the ones who play hard to get that are always the sweetest prey." That is what makes 
Belle appealing. She hasn't made a fool of herself just to gain my approval." The explanation was made to make Lefou understand that Gaston would not give up in order to obtain quantity because Gaston provides Lefou with excessive information.

Datum 3

here?"

Beast : "What are you doing

Belle : "I've come for my father"

The conversation occurred between Belle and the Beast, as shown in the dialogue above. He dislikes strangers entering his castle. So he was curious about what she was doing in the castle. Belle's response to Beast's question is extremely informative. Belle announced that she was on her way to see her father. It denotes that her utterance contained a quantity maxim. Beast's question is answered because she provides useful information.

Datum 4

Belle: "Who's there? Who are you?"

Beast: "The master of his castle."

The conversation in the preceding dialogue took place between Belle and Beast. He responds to the question in an informative manner. It implies that the Beast's utterance contained the maxim of quantity because the information was informative, not less or more informative than was required, as he is the master of the castle.

\subsubsection{Flouting of Maxim Quality}

Participant will make the floating maximum of quality because the participant lies or says something wrong and denies it so that someone else does not punish him. When the participant flouts, he or she uses an irony statement. Finally, the information is distorted by the speaker. It means that misrepresents the information in order for the addressees to understand.

Datum 1

Lumiere : "You must forgive first impressions, I hope you are not too starled."

Belle : "Why would I be starled? I'm talking to acandle."

Lumiere : "Candle labra please, Enormous different, but consider me at your service. The castle is your home now, so feel free to go anywhere you like."

\section{Cogs worth : "Except the west} wing... which we do not have,"

Belle

: "Why? What's in the west wing?"

Lumiere : "Nothing..."
Cogsworth :"Nothing"

According to Grice's theory about the maxim of quality, this requires the speaker to speak the truth. Cogsworth states in the conversation that there is no west wing in the palace with the sentence "Except the west wing... which we do not have," but there is, but the west wing is the secret palace that strangers cannot access. The west wing is a secret palace used by Beast to save the curse roses given by the fairy on that fateful night after she condemned the palace and everyone in it. Lumiere and Cogsworth are two people get the curse, they turn into the explanation above it can be concluded that Cogsworth has violated maxim of 
quality because he does not tell the truth about the west wing.

Datum 2

\section{Beast : "Who are you? \\ What are you doing here?" \\ Maurice : "I was lost in the \\ wood sand..." \\ Maurice responds to Beast's} question by saying, "I was lost in the woods and..." However, Beast does not believe what Maurice says and interrupts him before he finishes speaking. Maurice's utterance exemplifies the quality maxim because he was telling the truth about being lost in the woods.

Datum 3

Beast : "So, you've come to stare at the beast, have you?"

Maurice : "Please, I mean

no harm. I just needed a place to stay"

Maurice provides such accurate information in the preceding dialogue. As a result, his utterance contained a quality maxim. He was telling the truth when he said he came to the castle simply to find a place to stay.

Datum 4

Someone in tavern : "Gaston, did you try to kill Maurice?

Gaston

: "Maurice,
thanks
heaven!
I've spent
the last
five days
trying to
find you."

Maurice : "You try to

kill me. You left me to the wolves."

To keep his good name, Gaston lied when answering a question from someone in the tavern with the phrase
"Maurice, thanks heaven!" I've spent the last five days trying to find you." In fact, Gaston is attempting to murder Maurice and abandon him in the forest, hoping that Belle will fall into his arms because she has no one else in the village to protect her, and of course Belle will think about it. However, in the film, Maurice is rescued by Agathe, a woman who frees Maurice from the tree ties in the forest while searching for firewood and brings him back to the village.

\subsubsection{Flouting Maxim of Manner}

When someone uses ambiguous language, the participant flouts maxim manner. It uses another language that the participant does not understand, such as a foreign language. Sometimes the participant uses this flout to overdo things. It means that the participant is more important. In addition, slang is used by participants before people who do not understand. Finally, if the participant's voice is not loud enough, this maxim is blinded.

Example :

Datum 1

Gaston "Look, at her
Lefou. My future
wife. Belle is the
most beautiful girl
in the village that
makes her the
best."
: "She's so well
Lefou you are so
read.. and you
athletically inclined."
Gaston :I know."

The conversation that deviates from the manners maxim. Grice stated in 1976 that the speaker must avoid obscurity expression in Maxim of manner. Obscurity expression occurs 
when Lefou conveys Gaston's personality, which is very different from Belle's, as seen through Lefou's slightly hesitant manner and pauses in the sentence he wishes to convey.

Datum 2

$\begin{array}{ll}\text { Gaston } & \begin{array}{l}\text { "You are the } \\ \text { wildest.. most } \\ \text { gorgeous thing I } \\ \text { have ever seen. } \\ \text { Nobody deserves } \\ \text { you. But at least I } \\ \text { know our children } \\ \text { will be beautiful." }\end{array} \\ & \text { : "Am I catching } \\ \text { Lefou } & \\ \text { you bad time?" } \\ \begin{array}{l}\text { Gaston } \\ \text { Lefou?" } \\ \text { Lefou } \\ \text { is indistress." } \\ \text { According to Grice's theory about }\end{array}\end{array}$
the maxim of manner, which requires the speaker to avoid ambiguity. The damsel in ambiguity is in trouble." Gaston, please. Lefou should be able to communicate that Belle is in poor health, but because Gaston and Lefou share the same knowledge, Gaston can go directly to the location indicated by Lefou.

\subsubsection{Flouting Maxim of Relation}

Few reasons why participants do not respect relationship rules as much as possible. One is the unparalleled conversation. The participants usually do the wrong thing. They don't want to talk the same subject, they're going to change the subject or they can't talk about anything. Usually, this violation hides something. This means that the participants keep secret or something so nobody knows.

Datum 1
Gaston : "Belle wonderful book you have there."

Belle

: "Have you read it?"

Gaston

: "Well, not that one. But you know books.. for you dinner table (giving bunch of flower) shall I join you this evening?"

evening."

Belle : "Sorry, not this

The sentence "Well, not that one." in the preceding conversation flouting the relation maxim. But you know books... for your dinner table (handing over a bouquet of flowers), shall I join you this evening?" It's because Gaston tried to divert the conversation away from the book by suddenly giving Belle a bouquet of flowers and inviting her to dinner. Gaston committed the offense because he did not want Belle to know that he disliked reading books.

Datum 2

Belle : "You know
Shakespare?"
Beast " "I had an
expensive education,"

Belle : "Actually, Remeo and Juliet's my favorite play."

Beast's statement, "I had an expensive education," seemed less appropriate for the conversation at the time. According to Grice's theory about the maxim of relation, which states that the speaker and the hearer must be relevant in order to communicate, the conversation violated the maxim of relation because it did not discuss the education that Belle and Beast have.

Datum 3 
Belle : "By the way, thank you for saving my life"

Beast

"You're

\section{welcome"}

The conversation took place in the castle when Belle was being treated by Beast, as shown in the dialogue above. "By the way, thank you for saving my life," she added. Beast responds with such pertinent information. It indicates that the dialogue contained the relational maxim, which is Beast said you're welcome to respond to Belle's expression.

\section{CONCLUSION}

Then, based on the violation of maxims, there are four types of maxims, namely maxims of quality, maxims of quantity, maxims of relationship, and maxims of manner. There are 4 data including maxim of quality, 4 data including maxim of quantity, 3 data including maxim of relevant, then 2 data including maxim of manner. The results showed that the maxims that were most frequently violated in Beauty and The Beast were maxims of quantity and maxims of quality. Based on the findings above, the writer concludes that in the conversational fluting maxim in Beauty and The Beast there are many meanings contained in the conversation, as well as in everyday life we must pay attention to the conversational fluting maxim, because sometimes the fluting maxim can give the speaker misunderstanding. So its use should really be considered.

\section{REFERENCES}

Ambalegin, D., \& Suryani, M. S. (2018). Morphosyntactic analysis of inconsistent formation of English words, phrases, and sentences. 200(Aisteel), 472-478. https://doi.org/10.2991/aisteel18.2018.102

Barat, K. (2017). Metadata, citation and similar papers at core.ac.uk 104 /. 7(1), 104-126.

Creswell, J. W. (2007). Research design: Qualitative, quantitative and mixed method approaches. SAGE Publications.

Grice, P. (n.d.). Studies in the way of words -Harvard University Press (1991) (1) (1).pdf.

Kurniati, M., \& Hanidar, S. (2018). The flouting of the gricean maxims in the movies Insidious and Insidious 2. Lexicon, 5(1), 65-76. https://doi.org/10.22146/lexicon.v $5 i 1.41282$

L. Mey, J. (2018). Pragmatics: An introduction 2nd edition. In Corpus Linguistics for Pragmatics (pp. 115).

Levinson, S. C. (2000). Presumptive meanings: The theory of generalized conversational implicature cover. In Bradford Books.

Marlisa, R., \& Hidayat, D. N. (2020). The analysis of flouting maxim in Good Morning America (GMA) talkshow. Journal of Language, Education, and Humanities, 7(2). https://jurnal.arraniry.ac.id/index.php/englisia/arti cle/view/6630/4134

Mcafee, C. (2004). The linguistic relativity theory and Benjamin Lee Whorf. The McMaster Journal of Communication, 1(1), 26-31.

Meyer, C. F. (2009). Introducing English linguistics. Cambridge University Press 
Op.Sunggu, E. J., \& Afriana, A. (2020). Flouting maxims in "Wonder Woman" movie. Linguistic, English Education and Art (LEEA) Journal, 4(1), 1-12. https://doi.org/10.31539/leea.v4i 1.1394

Salzmann, Z., Georgakopoulou, A., \& Goutsos, D. (1999). Discourse Analysis: An Introduction. In Language (Vol. 75, Issue 3). https://doi.org/10.2307/417076

Sudaryanto. (1993). Method dan teknik analysis bahasa. Duta Wacana University Press.

Thomas, J. (1995). Meaning in interaction: An introduction to pragmatics. Pearson Education.

Yule. (1996). Pragmatics. Oxford University Press

Yule, G. V. T. N. F. (2015). Book Review "Pragmatic" By George Yule. January 2015, 1-21. 
elSSN 2747-1926 pISSN 2774-1605 